\title{
Antioxidant Activity and Bioactive Components of Curry Leaves (Murraya koenighii) to Lower Red Meat Cholesterol: Morphological, Chemical Content Curry Leaves and Putrefaction Test of Meat
}

\author{
Yurleni $^{1}{ }^{*}$ Adriani $^{1}$ \\ ${ }^{123}$ Department Animal of Production, Animal Science Faculty, Universitas Jambi. \\ *Corresponding author: yurleni_fapet@unja.ac.id
}

\begin{abstract}
This study aimed to determine the morphological characterization, area, chemical content of curry leaves, and the use of curry leaf extract in inhibiting the putrefaction process of meat stored at cold temperatures. The method used in this research was the exploration method. The number of leaves used for the analysis of the area and morphological characteristics of the leaves were 50 and came from different stems. The curry leaves used for chemical analysis came from 10 curry different stems. Morphological characteristics and chemical content were carried out on young, medium, old leaves, and respectively represented by the lower, middle, and upper leaves. Leaf morphological characteristics and meat decomposition tests were carried out at the Laboratory of the Faculty of Animal Science, Jambi University, while the chemical content of leaves was carried out at the Animal Husbandry Research Institute, Ciawi, Bogor. The data collected included leaf length, leaf width, leaf area, leaf morphological characteristics (leaf surface, leaf bone, leaf edge, leaf tip, leaf colour, leaf base, and several leaves), and chemical content of the young, medium, and old leaves, $\mathrm{pH}$, eber test, Postma test. The design used for the decomposition test and chemical content of the leaves was completely randomized. The area data and leaf morphological characteristics were analysed descriptively. The results showed that on the surface of curry leaves, the shape is slippery, the leaf bones are pinnate, the tip of the leaf is tapered, the edge of the leaf has serrated, the base of the leaf on the old one is pointed, the column of the leaves is the darker green, the number of leaves is 12-26. The average area of young, medium, and old leaves was $2.7 ; 3.5$ and $4.8 \mathrm{~cm} 2$. Meanwhile, the chemical content between young, medium, and old leaves was significantly different $(\mathrm{P}<0.05)$. The use of curry leaf extract had a significant effect $(\mathrm{P}<0.05)$ on meat $\mathrm{pH}$ and eber test. Based on the results, it can be concluded that the increasing level of leaf development, the older the leaf column, the larger the leaf area and the chemical content, especially protein related to metabolite compounds, increases. The use of curry leaf extract can inhibit the spoilage process of meat stored for 8 days at cold temperatures.
\end{abstract}

Keywords: Curry Leaves, Morphological Characters, Chemical Content, Leaf Area, Putrefaction Test of Meat.

\section{INTRODUCTION}

The curry plant (Morraya Koenigii L. Spreng) has great potential in Jambi Province because it is easy to grow and the common people use it as a spice in processed meat. Curry leaves produce essential oils that have been widely used as cooking spices [1][2]. Curry leaves also have antibacterial properties [3], antioxidants [4], and antimicrobials [5].

The function of the leaves in the curry plant is a very important part, namely the place where photosynthesis occurs. The size of the leaf function in plant growth causes differences in plant biomass production due to differences in the ability of leaves to produce reduced carbon to produce plant biomass. Therefore, leaf development is feasible as the main parameter in plant growth analysis [6][7][8].

Curry leaves are smaller than bay leaves and are compound leaves that are pinnate in shape and have long stalks, each stalk is an odd number consisting of 11-21 leaves. Regarding leaf growth, fast and precise measurement techniques are needed, one of which is using the millimetre column method. Leaf area 
estimation can also be done with millimetre chart paper [9][10].

Curry leaves have nutritional/chemical and nonnutritional content (secondary metabolites) such as vitamins, minerals, dietary fibre, beta carotene, and chlorophyll. The nutritional content contained in curry leaves consists of water content $(66.3 \%)$, protein $(1 \%)$, fat $(1 \%)$, carbohydrates $(16 \%)$, fibre $(6.4 \%)$, and minerals $(4.2 . \%)$ [11]. Content of $6.1 \%$ protein, $1 \%$ fat, $16 \%$ carbohydrates, and $6.4 \%$ fibre [12]. Different characteristics and chemical content of curry leaves depend on many factors that influence it.

Curry leaves contain polyphenol compounds and are included in a group of proteins that have antibacterial properties so they can extend food storage. One type of food that decomposes quickly is meat because the meat is a good medium for bacterial growth. To extend the shelf life of meat, curry leaves can be used as a natural preservative. Using curry leaf extract in the form of a powder with a concentration of $25 \%$ and $50 \%$ can extend the shelf life of meat. At a concentration of $25 \%$, the shelf life of meat is up to 5 days, while at a concentration of $50 \%$ the shelf life of meat is more than 7 days at $4^{\circ} \mathrm{C}$ [13]. Based on the description above, research has been carried out on the morphological characteristics, chemical content of curry leaves, and meat rot tests during storage.

\section{METHODOLOGY}

\subsection{Method of collecting data}

The research that was conducted was experimental. The object of research were the leaves of the curry plant that grows in Jambi City. Curry leaves were used for morphological characteristics analysis and leaf area identification was taken from 50 different trees. To calculate the leaf area, the millimetre block method was used [14]. The stages in the calculation using the millimetre block method were 1) Preparing millimetre block paper. 2) Selecting the leaves to be observed, namely the high, medium, and low leaves. 3) The plucked leaves were drawn on millimetre block paper (Figure 1). 4) Next measuring and counting the number of squares (in $\mathrm{cm} 2$ ) contained in the leaf image. 5) The edges of the leaves less than half of the box were not counted while those of more than half of the boxes were counted as $1 \mathrm{~cm} 2$. 6) To obtain the total leaf area per plant, the number of high leaf area, medium leaf area, and low leaf area is then divided by 3 .

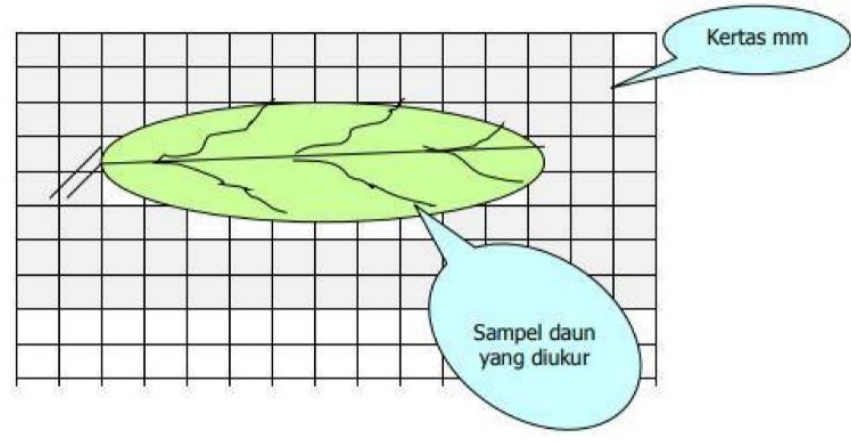

Figure 1. Calculating Leaf Total Area

The leaves of the curry plant used for chemical analysis came from 10 curry trees in Jambi City. The analysis of the chemical content of meat was according to AOAC [15]. Chemical content analysis was carried out at the Animal Husbandry Research Institute, Ciawi, Bogor. Data were collected by dry matter, fat, protein, crude fibre, ash, energy, and minerals on young, medium, and old leaves.

Mutton was utilized to do a test for spoilage of meat. The curry leaf extract used was obtained by maceration using a water solvent, which was done by boiling the simplicia powder of curry leaves in boiling water for 2 hours. The simplicia powder of curry leaves was mixed into water with a ratio of $1: 5(\mathrm{w} / \mathrm{v})$, then boiled at $100{ }^{\circ} \mathrm{C}$ for 2 hours. The results of the curry leaf simplicia powder were filtered with Whatman No 1 paper and accommodated in a plastic container. Boiling the simplicia of curry leaves in water was repeated 3 times. The filtrate from boiled 1, 2, and 3 were collected and concentrated by rotary evaporator at a temperature of $50^{\circ} \mathrm{C}$ until a dry extract was obtained.
The curry leaf extract was rubbed on the surface of the meat sample according to the treatment. There were 3 treatments (P0: goat meat without curry leaf extract spread, P1: mutton smeared with $25 \%$ curry leaf extract, P2: mutton smeared with $50 \%$ curry leaf extract) and each was repeated 5 times. The parameters of the spoilage test consisted of $\mathrm{pH}$, eber test, and posttest

\subsection{Work procedures:}

\subsection{1 $\mathrm{pH}$}

Measurement of $\mathrm{pH}$ values was carried out using a $\mathrm{pH}$ meter. The electrode tip of the $\mathrm{pH}$ meter was rinsed with distilled water and then dried with a tissue. The $\mathrm{pH}$ meter was then calibrated with the electrode dipped in a buffer solution of $\mathrm{pH} 4$ and $\mathrm{pH}$ 7. The electrode was immersed in the sample until you see the results in the $\mathrm{pH}$ meter. 


\subsubsection{Eber test}

The meat was placed hanging over the eber reagent in a test tube. Observe the changes that occurred if a white cloud appeared around the meat, it meant that the meat has gone through the initial process of spoilage. However, if a white cloud did not appear around the meat, it meant that the meat has not undergone the initial process of spoilage. Note the time the white cloud appeared.

\subsubsection{Postma test}

As much as 5 grams of meat were crushed using a mortar and pestle then put into the Erlenmeyer flask. 50 $\mathrm{ml}$ of distilled water that has been boiled and has cooled back to room temperature was mixed with the ground meat. The mixture of meat and distilled water (meat extract) was let stand for 15 minutes. After that, it was filtered and $10 \mathrm{ml}$ of the meat extract was then put into a petri dish containing $100 \mathrm{mg}$ of $\mathrm{MgO}$. After the meat extract and $\mathrm{MgO}$ were mixed, the $\mathrm{pH}$ meter paper was put into the petri dish. The petri dish was closed and then put in a water bath at $50{ }^{\circ} \mathrm{C}$ for 5 minutes. After 5 minutes, observe the colour change that occurred on the red litmus paper, if the red litmus paper turns blue, it means that the decay process has been described by the release of $\mathrm{NH}_{3}$ gas which is captured by the red litmus paper.

\subsection{Data Analysis}

Leaf area data and morphological characteristics were analysed descriptively and qualitatively (multiplication, addition, and mean). The chemical content of curry leaves and the putrefaction test on the meat used a completely randomized design (CRD) and analysed using variance and if the treatment was significantly different then continued with the Duncan test [16].

\section{RESULT AND DISCUSSION}

\subsection{Morphological Characteristics of Curry Plant Leaves}

The leaf is one part of the plant organ that develops. Leaves contain chlorophyll. Chlorophyll which is widely contained in leaves has the ability to be anti-oxidant, anti-inflammatory, and a substance that can heal wounds [17]. Leaf morphological characteristics are one of the characteristics of the leaves and can be seen in real terms and different shapes. Morphological characteristics include leaf surface, leaf bone, leaf edge, leaf tip, leaf colour, leaf base, and several leaves (Table 1).

Table 1. Morphological characteristics of the young, medium, and old curry leaves

\begin{tabular}{lccc}
\hline Leaf Morphological & \multicolumn{3}{c}{ Leaf Grow Level } \\
\cline { 2 - 4 } Characteristic & Young Leaf & Medium Leaf & Old Leaf \\
\hline Leaf Surface & Delicate & Delicate & Delicate \\
Leaf Bone & Pinnate & Pinnate & Pinnate \\
Leaf Tip & Pointing & Pointing & Pointing \\
Leaf Edge & Fine Serrated & Fine Serrated & Fine Serrated \\
Leaf Base & Pointed on one side & Pointed on one side & Pointed on one side \\
& Rounded on another side & Rounded on another side & Rounded on another side \\
Leaf Colour & Bright Lime Green & Dark Green & Darker Green \\
Total Leaf & $12-26(19 \pm 3.28)$ & $15-26(21 \pm 2.41)$ & $13-25(21 \pm 2.43)$ \\
\hline
\end{tabular}

In the table above, it can be seen that the surface morphological characteristics of the young, medium, and old curry leaves are smooth, pinnate leaf bones, tapered leaf tips, and finely serrated leaf edges. while the base of young and medium leaves has the same pattern, that is, one side is tapered and the other side is slightly rounded, the base of the old leaves is different from the young and medium leaves.

Leaf colour differs between young, medium, and old. The difference in leaf colour indicates a difference in leaf pigment content including chlorophyll pigment. The chlorophyll in young leaves is still a protochlorophyllide and the leaves turn green after the protochlorophyllide transformation [18]. The reduction of protochlorophyllide to become chlorophyll-a which is green-blue requires light, and this light is absorbed by the protochlorophyllide to convert itself into chlorophyll-a. This event is called auto transformation [19]. Chlorophyll-a $\left(\mathrm{C}_{55} \mathrm{H}_{70} \mathrm{O}_{6} \mathrm{~N}_{4} \mathrm{Mg}\right)$ is dark green and chlorophyll-b $\left(\mathrm{C}_{55} \mathrm{H}_{70} \mathrm{O}_{6} \mathrm{~N}_{4} \mathrm{Mg}\right)$ which is light green. The synthesis of chlorophyll $\mathrm{b}$ continues along with the development of leaves, which is marked by changing the colour of light green leaves to dark green.

\subsection{Curry Leaf Area}

One of the important plant growth variables is the leaf area. Leaf area size reflects the level of plant fertility and is also related to the ability of plants to photosynthesize. The results of measurements of the curry leaf area can be seen in Table 2 . 
Table 2. The average area of young, medium, and old curry leaves

\begin{tabular}{lllcc}
\hline No & Leaf Growth Level & \multicolumn{1}{c}{ Length $(\mathrm{cm})$} & Wide $(\mathrm{cm})$ & Area $(\mathrm{cm} 2)$ \\
\hline 1 & Young Leaf & $3.5-7.6(5.7 \pm 0.55)$ & $1.0-1.6(1.3 \pm 0.2)$ & $1.3-4.2(2.7 \pm 0.9)$ \\
2 & Medium Leaf & $3.6-8.6(6.3 \pm 0.54)$ & $1.1-1.9(1.5 \pm 0.2)$ & $1.5-5-4(3.5 \pm 1.0)$ \\
3 & Old Leaf & $3.8-10.4(7.3 \pm 0.76)$ & $1.2-2.3(1.7 \pm 0.3)$ & $1.8-7.9(4.8 \pm 1.7)$ \\
\hline
\end{tabular}

In table 2 it can be seen that there is an increase in leaf length, leaf width, and leaf area with increasing leaf age. The average area of young curry leaves was 2.7 $\mathrm{cm} 2$ and increased to $3.5 \mathrm{~cm} 2$ on medium leaves and old leaves to $4.8 \mathrm{~cm} 2$. The results of this study are in the area of lampeni leaves [17]. As the leaves age, there is an increase in the length, width, and area of the leaves [20].

New leaves develop from leaf primordia that are formed on the apex meristem. Each leaf primordial is formed on the pelvic meristem of the shoot apex. When the primordial of a new leaf is formed, the primordial of the previous leaf (which is older) has expanded progressively, as a result of the activity of the meristem in the leaf itself. The primordial leaves will continue to grow in size gradually so that they reach a certain size and shape. The increase in leaf size occurs as a result of an increase in the number of cells followed by an increase in cell size. The initial growth of leaves is actually due to the presence of a meristem tissue whose cells undergo intercalary divisions which are scattered randomly and cause an increase in leaf size followed by growth of the apex and leaf margins.

\subsection{Chemical Content of Curry Leaves}

Plant leaves contain various nutrients and nonnutrients. The nutritional or chemical content of curry leaves is closely related to its use as spices and medicinal ingredients. The chemical content of curry leaves based on the level of leaf development is presented in Table 3.

Table 3. Average chemical content of curry leaves based on level of development

\begin{tabular}{lccc}
\hline Nutritional Content $(\%)$ & \multicolumn{3}{c}{ Leaf Growth Level } \\
\cline { 2 - 4 } & Young Leaf & Medium Leaf & Old Leaf \\
\hline Dry matter (\%) & $26.83^{\mathrm{c}} \pm 4.62$ & $32.18^{\mathrm{b}} \pm 4.49$ & $36.46^{\mathrm{a}} \pm 3.99$ \\
Crude Protein $(\%)$ & $5.02^{\mathrm{b}} \pm 0.86$ & $5.58^{\mathrm{b}} \pm 0.78$ & $6.41^{\mathrm{a}} \pm 0.70$ \\
Crude fat (\%) & $1.71^{\mathrm{b}} \pm 0.29$ & $2.54^{\mathrm{a}} \pm 0.35$ & $2.75^{\mathrm{a}} \pm 0.30$ \\
Crude fiber (\%) & $5.26^{\mathrm{b}} \pm 0.91$ & $5.85^{\mathrm{b}} \pm 0.82$ & $8.08^{\mathrm{a}} \pm 0.88$ \\
Ash (\%) & $4.07^{\mathrm{b}} \pm 0.69$ & $4.27^{\mathrm{b}} \pm 0.59$ & $5.35^{\mathrm{a}} \pm 0.59$ \\
Energi (kkal) & $1215^{\mathrm{b}} \pm 209.06$ & $1478^{\mathrm{a}} \pm 505.14$ & $1642^{\mathrm{a}} \pm 179.81$
\end{tabular}

Note: Different superscripts on the same line indicate significantly different $(\mathrm{P}<0.05)$

Many metabolites are found in curry leaves. Primary metabolite compounds consist of carbohydrates, proteins, and fats [21]. From the table above, it can be seen that the protein content of curry leaves ranges from $4.57-5.81 \%$. The protein content of curry leaves was lower than that reported by Ophong [12], which was $6.1 \%$.

The increase in leaf development, namely the higher the protein content in old leaves, is closely related to metabolite compounds which are included in the protein group. Polyphenol compounds are included in the group of protein that functions as an antioxidant. Polyphenol compounds can slow down and prevent the oxidation process.

\subsection{Putrefaction test of meat}

The nutritional content of meat, especially protein and high water, is a good medium for the growth of pathogenic bacteria. Improper handling of meat can cause damage, namely rapid spoilage. To find out that the meat stored for 8 days at cold temperatures is still good, and initial spoilage test is carried out, namely by measuring the $\mathrm{pH}$, carrying out the eber test, and posttest. The mean $\mathrm{pH}$ of meat, eber test, and Postma test are presented in Table 4.

Table 4. Average $\mathrm{pH}$ of meat, eber test and Postma test on meat stored at a cold temperature for 8 days

\begin{tabular}{cccc}
\hline & \multicolumn{3}{c}{ Parameters } \\
\cline { 2 - 4 } & $\mathrm{pH}$ & Eber test (second) & Postma test \\
\hline P0 & $7.12^{\mathrm{a}}$ & $9.8^{\mathrm{b}}$ & Positif $(+)$ \\
P1 & $6.14^{\mathrm{b}}$ & $58^{\mathrm{a}}$ & Positif $(+)$ \\
P2 & $6.68^{\mathrm{a}}$ & $14^{\mathrm{b}}$ & Positif $(+)$ \\
\hline
\end{tabular}

Note: Different superscripts on the same colour indicate significantly different $(\mathrm{P}<0.05)$ 
From the table above, it can be seen that the treatment has a significant effect $(\mathrm{P}<0.05)$ on the $\mathrm{pH}$ of the meat and the eber test. The $\mathrm{pH}$ of the research meat ranges from 6.14-7.12. After the cattle are slaughtered, the $\mathrm{pH}$ decreases due to the accumulation of lactic acid in muscle tissue as a result of the anaerobic glycolysis process. The process of changing glycolysis to lactic acid stops in the $\mathrm{pH}$ range of 5.6-5.8. $\mathrm{pH}$ also affects bacterial growth, almost all bacteria grow optimally at $\mathrm{pH} 7$ and will not grow at $\mathrm{pH} 4$ or above $\mathrm{pH} 9$. Most

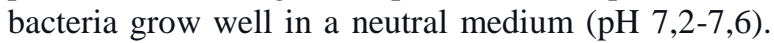
Research meat stored in cold temperatures occurs microbial growth but has not undergone a decay process, because rotten meat will have an alkaline $\mathrm{pH}$, namely between $\mathrm{pH} 8-\mathrm{pH} 14$. Rotten meat has increased $\mathrm{pH}$ due to decreased activity of acidproducing microbes due to increasingly limited glycogen supplies and followed by microbial activity producing alkaline compounds.

Meat that is putrefied will release $\mathrm{NH}_{3}$ gas faster, about 2-3 minutes. The meat from the research that is covered with curry leaf extract has not undergone a decomposition process, this is because the curry leaf extract can inhibit the putrefaction process caused by rotting bacteria.

Of the three tests conducted, only the Postma test detected that all positive samples had undergone the initial process of decomposition, but the meat had not rotted because of the $\mathrm{P} 1$ and $\mathrm{P} 2$ treatments which were still negative, around $40 \%$, meaning that the meat had not rotted but was in the early stages of decomposition.

\section{CONCLUSION}

The conclusion that the increasing level of leaf development, the older the leaf colour, the larger the leaf area, and the chemical content, especially protein related to metabolite compounds, increases. The use of curry leaf extract can inhibit the spoilage process of meat stored for 8 days at cold temperatures.

\section{ACKNOWLEDGMENT}

Acknowledgments are conveyed to LPPM Jambi University, which has funded the 2020 Higher Education Excellence Basic research through the Jambi University PNBP scheme. This research is part of the basic research conducted.

\section{REFERENCES}

[1] Hermawan, Daya saing rempah Indonesia di pasar asean periode pra dan pasca krisis ekonomi global. Buletin Ilmiah Litbang Perdagangan, 2015. 3(2). 153-178. DOI: https://doi.org/10.30908/bilp.v9i2.6.

[2] Fachraniah, E. Kurniasih, D.T. Novilasari, Ekstraksi antioksidan dari daun kari. J. Reaksi, 2012. $\quad 10 \quad$ (21): $35-44$. http://jurnal.pnl.ac.id/?p=1256.
[3] M.P. Rajendran, B.B. Pallaiyan, N. Selvaraj, Chemical composition, antibacterial and antioxidant profile of essential oil from Murraya koenigii (L.) leaves. Avicenna J Phytomed., 2014. 4 (3): $200-214$. https://www.ncbi.nlm.nih.gov/pmc/articles/PM C4104627/pdf/AJP-4-200.pdf

[4] A.K. Das, V. Rajkumar, D.K. Dwivedi, Antioxidant effect of curry leaf (Murraya koenigii) powder on quality of ground and cooked goat meat. Int. Food Research J, 2011. $18 \quad$ (2): 536-569. http://www.ifrj.upm.edu.my/volume182011.ht $\mathrm{ml}$.

[5] J. Shivkanya, P. Shilpa, K. Sangita, F. Neeraj, Pharmacognostical studies and antibacterial activity of the leaves of Murraya koenigii. Pharmacognosy J, 2009. 1(3): 210-214. http://phcogfirst.com/article/593.

[6] F.B. Salisbury, C.W. Ross, Fisiologi tumbuhan (Jilid 2) terjemahan Diah R. Lukman dan Sumaryono. Institut Teknologi Bandung. Bandung. 1995.

[7] S.M. Sitompul, B. Guritno, Analisis pertumbuhan tanaman. Gadjah Mada University Press. Yogyakarta, 1995.

[8] W.K. Nugroho, F. Yuliasmara, Penggunaan metode scanning untuk pengukuran luas daun kakao. Warta Pusat Penelitian Kopi Dan Kakao Indonesia, $24|1|$ Februari 2012. hal 5-8

[9] S.K. Pandey, H. Singh, A simple, cost-effective method for leaf area estimation. Journal of Botany, 2011. Volume 2011 (2011), Article ID $658240.6 \mathrm{p}$.

[10] I.G.A. Gunadi, Penuntun praktikum ekologi tanaman, 2014. https://simdos.unud.ac.id/ uploads/filependidikan_dir/427770b13dd826 d9dddcd359 ff4c0bd5.pdf. Diakses 25

[11] T. Aziz, S. Febrizky, A.D. Mario, Pengaruh jenis pelarut terhadap persen yield alkaloid dari daun salam india (Murraya koenigii). Teknik Kimia, 2014. 2(20):1- 6.

[12] Ophoeng, Daun Kari, 2015 http://www.herbalgram.org/, (diakses 15 Juli 2018)

[13] A. Safrijal, Razali, Ismail, T.R. Ferasyi, Nurliana, D. Masyitha, Effect of curry leaf (Murraya koenigii) extract to early spoilage of beef. Jurnal Medika Veterinaria, 2017. 11(2):82-87.

[14] Y. Sugito, Metodologi penelitian. Lembaga Penerbit FPUB. Malang, 1995.

[15] AOAC, Official methods of analysis. 21 st Edition, 2019. AOAC International.

[16] R.G.D. Steel, J.H. Torrie, Prinsip dan prosedur statistika, suatu pendekatan biometrik. PT. Gramedia Pustaka Utama, 1993.

[17] Setiawati, I. A. Saragih., M. Nurzaman., A. Z. Mutaqin, Analisis kadar klorofil dan luas daun lampeni (Ardisia humilis Thunberg) pada tingkat 
perkembangan yang berbeda di Cagar Alam Pangandaran. Prosiding Seminar Nasional MIPA, 2016. Jatinangor, Bandung. ISBN 978802-72216-1-1. hal 122-126.

[18] L. Sumenda, L.R. Henny, R.M. Feky, Analisis kandungan klorofil daun mangga (Mangifera indica $\mathrm{L}$.) pada tingkat perkembangan daun yang berbeda. Jurnal Bioslogos, 2011. 1 (1): 20-24

[19] Nio, Ai Song dan Y. Banyo, Konsentrasi klorofil daun sebagai indikator kekurangan air pada tanaman. Ilmiah Sains, 2011. 11(2): 166173

[20] G.P. Yudha, Z.A. Noli, M. Idris, Pertumbuhan daun angsana (Pterocarpus indicus Willd) dan akumulasi logam timbal $(\mathrm{Pb})$. Jurnal Biologi Universitas Andalas (J. Bio. UA.)., 2013. 2(2): 83-89.

[21] Nayak, S. Mandal, A. Banerji, J. Banerji, Review on chemistry and pharmacology of Murraya koenigii spreng (Rutaceae). J Chem Pharm Res, 2010. 2: 286-299. 